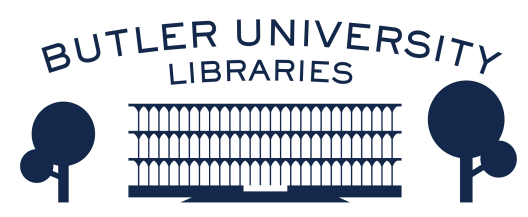

Volume 22

\section{Journal of Hindu-Christian Studies}

Article 19

January 2009

\title{
Book Review: "Sacrifice and Cosmos: Yajña and the Eucharist in Dialogue"
}

Swami Tyagananda

Follow this and additional works at: https://digitalcommons.butler.edu/jhcs

Part of the Religion Commons

\section{Recommended Citation}

Tyagananda, Swami (2009) "Book Review: "Sacrifice and Cosmos: Yajña and the Eucharist in Dialogue"," Journal of Hindu-Christian Studies: Vol. 22, Article 19.

Available at: https://doi.org/10.7825/2164-6279.1446

The Journal of Hindu-Christian Studies is a publication of the Society for Hindu-Christian Studies. The digital version is made available by Digital Commons @ Butler University. For questions about the Journal or the Society, please contact cbauman@butler.edu. For more information about Digital Commons @ Butler University, please contact digitalscholarship@butler.edu. 


\section{Sacrifice and Cosmos: Yajña and the Eucharist in Dialogue. George Praseed, IMS. New Delhi: Decent Books, 2009, 413 pp.}

MUCH scholarly work has been done on the general theme of sacrifice, but the relationship between sacrifice and the universe has received minimal attention, a lacuna that the present book seeks to fill. Fr. George Praseed attempts to show how sacrifice as a ritual is the key to understand the interrelationship between God, the universe, and human beings. The study, structured around the Hindu "Yajña" and the Christian "Eucharist," provides a comparative framework in which the spiritual visions of the two traditions are compared and contrasted in a balanced and respectful manner. Divided into three parts, the book deals with Yajña in the first, the Eucharist in the second, and makes a comparative study of the two in the third.

Sacrifice has been seen variously as a "gift," as a "communion," and as a "communication" between the sacred and the profane. Praseed views it primarily as a "ritual repetition" of creation of the world and a "ritual action" that maintains the world. He analyzes the PurushaSūkta (Rig-Veda 10.90) as a prototype Vedic sacrifice to demonstrate its cosmic significance in the creation and maintenance of the world, affirming that "the cosmos is the product of sacrifice, the sacrifice is in the beginning of everything" (47). Two Vedic rituals connected with the Purusha-Sūkta, Aśvamedha and Agnicayana, are analyzed to show that "sacrifice is the beginning of all realities and to sacrifice is to make sure the survival of oneself and of the whole cosmos" (114). The Vedic vision was interiorized in the Upanishads, which privileged the mystic experience of nonduality in Brahman/Ātman over the ritualistic sacrifice found in the Brāhmanas, the earlier section of the Vedas. This paved the way for the emergence of devotion (bhakti) in the Gita, where sacrifice was equated with self-discipline, selfless work and self-surrender to God.

According to Praseed, whereas the cosmic dimension of the Vedic sacrifice is "almost selfevident," it is "hidden" in the Eucharistic sacrifice. The reason for this is the lack of cosmic vision in the Eucharistic theology. The relation between the Eucharist and the cosmos was recognized by the Orthodox theologians but neglected by Catholic and Protestant theologians. The general tendency among Christians is to view Christian sacrifice as primarily spiritual, not ritual. Praseed seeks to prove the opposite; namely, that it "not merely spiritual but ritual and, only as a ritual, can it have a true cosmic value" (176). He avoids the reductionistic trap by approaching the theme from both directions: descending (God offering to humans in sacrifice) and ascending (humans offering themselves to God in the Eucharist). This he does by discussing the truly sacrificial nature of the Last Supper and Jesus' self-giving to the Father on the cross. Praseed contends that Protestants failed to understand the Catholic position on the Eucharist as sacrifice. He affirms that neither Jesus' sacrifice nor the sacrificial nature of the Eucharist should be denied. He analyzes the views of Maximus the Confessor, V. Lossky, J. D. Zizioslas, and Teilhard de Chardin to show that in all of them the Eucharistic sacrifice has a cosmic dimension.

A comparative analysis of Yajña and the Eucharist shows both the Vedic primordial man (purusha) and Christ to be the creator and sustainer of all creation. While the Vedic sacrifice is the ritual repetition of the self-giving sacrifice of purusha, the Eucharist is the ritual memorial of the death and the resurrection of Jesus Christ. Both the Vedic sacrifice and the Eucharist are means for 'the existence and survival of the cosmos, and both are also the means by which immortality can be attained. Food is another point of convergence: while Brahman is the "food of life," Jesus is the "bread of life" (307). There are significant differences as well between Yajña and the Eucharist. One obvious difference is that the Vedic purusha is a mythical figure whereas Jesus is a historical person. Another difference is that for Vedic Hinduism the creation is through the sacrifice of the purusha while in Christianity the redemption is through the sacrifice of Jesus. 
The similarities between Yajña and the Eucharist become obvious in the Vedic five great daily sacrifices (pañca-mahāyajña). Praseed is at his comparative best in Chapter Seven of the book where he holds sacrifice to the gods (devayajña) alongside the Eucharist as sacrifice to God the Father; sacrifice to the dead (pitryajña) alongside the offering of the Eucharist for the dead; sacrifice to all living beings (bhütayajña) alongside the intercession for the well-being of all in the Eucharist; sacrifice to human beings (nryajña) alongside the Eucharist as the agapic meal; and sacrifice to
Brahman (brahmayajña) alongside the liturgy of the Word.

Originally written as a doctoral dissertation presented to the Institute of Pastoral Liturgy, Abbey of St. Justine, Padua (under the author's old name George Padinjattukara Varkey), the book is both insightful and informative even if somewhat wordy and repetitive. Praseed quotes profusely from theologians past and present, and provides a useful glossary and a bibliography.

Swami Tyagananda

Harvard University

\section{Kurisumala: Francis Mahieu Acharya-A Pioneer of Christian Monasticism in India. Marthe Mahieu-De Praetere. Trans. by Susan Van Winkle. Kalamazoo, Mich.: Cistercian Publications, 2007, xv + 394 pp.}

WESTERN scholars of the contemporary Hindu-Christian encounter are familiar with the towering figures, Swami Abhishiktananda and Bede Griffiths, and with their institution, Shantivanam Ashram. Much less is commonly known among scholars about their one-time confrere, Francis Acharya (1912-2002). Acharya and Griffiths had together founded Kurisumala Ashram, an institution that is strong and thriving today, so it is surprising that Acharya is not better known. However, this situation may soon change, for Acharya's niece, Marthe Mahieu-De Praetere, has written the first biography of him. It was first published in Belgium in 2001 and an English translation was published in 2008.

Francis Acharya was born as Jean Mahieu to a wealthy, Catholic family in Ypres. The young Mahieu could have had a very successful career in his father's Union Factory, but he had a life changing experience in 1931 while he was a student in England. He caught sight of Gandhi on the latter's famous visit to London and was impressed by the man's display of simplicity before the pomp of the British Empire. He stated, "For me, it was the victory of a man who incarnated poverty. It was the epiphany of a purely spiritual power and I dreamt of following the same path" (22). Mahieu dismayed his father four years later by entering the monastery of Our Lady of Scourmont in Chimay, where he followed a very ascetical lifestyle. In the coming decades he nurtured an interest in Indian spirituality and gained permission in 1955 from his superiors to move to India. There he joined Jules Monchanin and Swami Abhishiktananda at Shantivanam Ashram, which had been established four years earlier. Mahieu was fascinated by their project of integrating Christian monasticism with Indian culture.

Acharya's interests quickly moved away from Shantivanam. Soon after his arrival in India in 1955 he met Raimundo Panikkar, who introduced him to Bishop René Feuga of Mysore. The bishop, in turn, introduced Acharya to some of the thriving Christian communities of Kerala. Acharya was deeply enchanted by the vibrant community life and the Syriac liturgies he encountered, versions of which had been celebrated in India since the earliest eras of church history (139-42). Acharya had a great love of the early Christian theologians of the East, and the Syriac liturgy was a living link to that world $(82,98)$. Further, he was disappointed that Shantivanam was failing to attract new members and to build a strong community life. Acharya hence resolved to found a monastery in 